\title{
Organizational Citizenship Behavior, Job Satisfaction and Commitment to School: Is There Any Significant Difference between Male and Female Teachers?
}

\author{
Hossein Jenaabadi ${ }^{1, *}$, Ehsan Okati ${ }^{1} \&$ Aliyavar Sarhadi ${ }^{1}$ \\ ${ }^{1}$ Department of Education and Psychology, University of Sistan and Baluchestan, Zahedan, Iran \\ *Corresponding author: Department of Education and Psychology, University of Sistan and Baluchestan, Zahedan, \\ Iran. E-mail: hjenaabadi@ped.usb.ac.ir
}

Received: April 7, 2013

Accepted: May 15, $2013 \quad$ Online Published: June 20, 2013

doi:10.5430/wje.v3n3p75

URL: http://dx.doi.org/10.5430/wje.v3n3p75

\begin{abstract}
This research investigated the gender differences in job satisfaction, organizational commitment and organizational citizenship behavior in sample included 200 male and 200 female teachers and 80 male managers in boy elementary schools in Zahedan. Data was collected by means of questionnaires and was analyzed through Factorial Analysis of Variance, Pearson Fisher Correlation, Structural Equations Modeling, and Multiple Regression. The results show that the mean of female teachers in variables is significantly more than male teachers, but the correlation between variables is significantly more in male teachers. Moreover the modified models of intrinsic job satisfaction, organizational commitment and organizational citizenship behavior in male teachers have fitted well with data. Although the standard coefficients of direct and indirect effects were more in the models of male teachers, but they did not have significant difference with female teachers standard coefficients. The male teachers' model explained more variance of organizational citizenship behavior. The results have been discussed with emphasis on the reasons of gender differences.
\end{abstract}

Keywords: organizational citizenship behavior; intrinsic job satisfaction; extrinsic job satisfaction; organizational commitment; gender differences; male and female teachers

\section{Introduction}

Human resource is considered as one of the most valuable organizational capital, the most important competitive advantage and the scarcest resource in today's knowledge-based economy. Since this valuable capital has tremendous effect on the effectiveness of the organization, it can be seen as the most important organizational capital. Accordingly, nowadays the organizations and managers applying different strategies and techniques try to recruit the best and the most skillful human resources (Belcourt, Bohlander, \& Snell, 2008). Organizational citizenship behavior is one of the valuable characteristics of human resource which has attached much attention nowadays. This variable by inspiration of a good citizen describes an employee as who have done his best to carry out his duty and help the organization in general. In other words, the employees with organizational citizenship behavior, like committed citizens are willing to without expectations make effort for improving and promoting of the organization. Naturally, if the organizations have such employees, they won't be concerned about effectiveness, and in the field of competition they can comfortably invest in other effective fields on effectiveness. The managers also spend most of their time to affairs other than those related to duties of their subordinates (Organ, 1988).

Organ (1988) as one of the most effective persons in development of organizational citizenship behavior variable has noted some basic features of this variable. Inspired by his definition, it can be found that organizational citizenship behaviors are spontaneous behaviors and are less affected by external stimuli (such as reward and punishment). These behaviors have been optional and voluntary and their valuable nature will be violated if the employees are forced to show such behaviors or punished for not showing them. Moreover, these behaviors are not official duties of employees and are not mentioned in employment contract, so they will finally result in the effectiveness of organization. Podsakoff et al. (2002) conducted a comprehensive research. They reviewed and analyzed the 
published studies about organizational citizenship behavior and finally found 30 different forms of employee organizational citizenship behavior. Among them 5 characteristics were used more than others. They include: sacrifice (voluntary help to others and avoiding business problems and difficulties for them), dutifulness (internalizing and accepting organizational rules and regulations and observing them even when nobody is watching them), valiancy (the willingness to tolerate the problems of work, without expressing complaint and not waste time for complaining about unimportant matters in organization), courtesy(not violate the rights of other employees), civil virtue (too interest and high commitment to organization, and accepting that he is a small member of a big society).

It cannot be denied that organizational citizenship behavior is very important in different organizations, but this behavior gets more sensitive and crucial in the context of school. The role of schools in education of future human resources and in comprehensive development of countries is the main reason for the need to have teachers with high organizational citizenship behavior. The duty of teachers is to upgrade the students' learning through teaching. By considering the complex nature of learning, undoubtedly it cannot be created with high quality just through better performance and carrying out specific and predetermined duties (Oplatka, 2009).

The importance of organizational citizenship behavior in teachers like other organizations nowadays has resulted in providing a variety of research evidences. In spite of the similarity in definition of organizational citizenship behavior of teachers and other employees, there is a tendency to classify the structure of this variable according to its objectives in the school. The fact that who will benefit from teachers' organizational citizenship behaviors reveals a complex structure.

Organizational citizenship behavior of teachers can be applied to help students, other teachers, the school as a whole, competence and personal growth, classroom, manager and parents (Zeynabadi et al., 2009). Despite that organizational citizenship behaviors of teachers have addressed different persons, in studying the structure; some evidences (DiPaola, Tarter, \& Hoy, 2005) have found one-dimension structure.

\section{Methodology}

This research is considered as descriptive correlation study. All teachers and managers of boy public elementary schools in Zahedan make up the population of this study. The sample includes 400 teachers (200 male and 200 female teachers) and 80 male managers. Since the evidences (Wanxian \&Weiwu, 2007) have indicated that there is a significant relationship between age and organizational citizenship behavior, the age of sample was controlled. The male managers were chosen because the gender of manager effects the evaluation of teachers' organizational citizenship behaviors (Allen \& Rush, 2006). The sample was chosen through multistage cluster sampling method. In this method the population individuals are chosen randomly from larger units to smaller ones with respect to hierarchy of population units. In this study, the samples were selected from units including schools district 1 and boy public elementary schools in Zahedan. It is necessary to mention that the sample size is sufficient regarding the optimal sample size in correlation studies.

In analyzing data, the Factorial Analysis of Variance was used to examine the significance of difference between job satisfaction, organizational commitment, and organizational citizenship behavior of male and female teachers. Moreover, to estimate the correlation between the variables, Pearson Coefficient Correlation was calculated. Also to investigate the significance of difference between coefficients and the variables correlations in male and female teachers, Fisher's Z test was conducted. Furthermore to test the models and examine the direct and indirect effects and also compare the manner of fitting in male and female teachers models, the Structural Equation Modeling (SEM) with Maximum Likelihood Method was used. And finally Multiple Regression was conducted to compare the ability of male and female teachers in explaining the organizational citizenship behavior.

\section{Data Collection Instruments}

Four questionnaires were applied in the study. About the process of instrument preparation, it should be noted that the questionnaires were first translated to Persian and then two English language experts were asked to translate them to English. The difference between English and Persian versions were evaluated and reduced to minimum. The differences were carefully examined according to the semantic synonymy of two English and Persian versions. Subsequently, some of the faculty members confirm the validity of content and cultural adaptation of the questionnaires. All four questionnaires are accompanied by a 5-point response scale ranging from strongly disagree to strongly agree. 


\section{Results}

Table 1 shows the mean and the standard deviation of the intrinsic job satisfaction, the extrinsic job satisfaction, the organizational commitment, and the organizational citizenship behavior in male and female teachers.

Table 1: Descriptive Indexes of Variables in Male and Female Teachers

\begin{tabular}{clcccc}
\hline Indexes & Gender & $\begin{array}{c}\text { Intrinsic job } \\
\text { satisfaction }\end{array}$ & $\begin{array}{c}\text { Extrinsic job } \\
\text { satisfaction }\end{array}$ & $\begin{array}{c}\text { organizational } \\
\text { commitment }\end{array}$ & $\begin{array}{c}\text { organizational } \\
\text { citizenship } \\
\text { behavior }\end{array}$ \\
\hline \multirow{2}{*}{ Mean } & Male & 3.66 & 2.59 & 3.73 & 3.56 \\
& Female & 4.38 & 3.30 & 4.13 & 3.86 \\
& Male & 0.80 & 0.60 & 0.87 & 0.49 \\
Standard & Female & 0.67 & 0.57 & 0.78 & 0.52 \\
Deviation & & & & & \\
\hline
\end{tabular}

\subsection{First Hypothesis}

There is a significant difference between job satisfaction, organizational commitment, and organizational citizenship behavior in male and female teachers.

The hypothesis was confirmed through significant level of Kolmogorov-Smirnov Test. Finally, covariance homogeneity hypothesis was approved through Box's M Statistics with amount of 19.553, and the quantity F of 1.934 with significant level of 0.36 . Therefore, the appropriateness of hypotheses indicates that the data are suitable for examining the difference between two genders both in linear combination and in separation. Table 2 indicates the results of this study. Among Pillai’s Trace Statistic, Hotelling‘s, Roy’s Largest Root, and Wilkss’ Lambda Statistic, the last one is usually reported for calculating $\mathrm{F}$ value.

Table 2: The Difference between Male and Female Teacher in Linear Combination of Dependent Variables (the intrinsic job satisfaction, the extrinsic job satisfaction, the organizational commitment, and the organizational citizenship behavior)

\begin{tabular}{llll}
\hline wilkss & F & Df & \\
\hline 0.646 & 50.090 & 4 & 0.337 \\
\hline
\end{tabular}

As the above table indicates the results of Factorial Analysis Of Variance by means of Wilkss' Lambda Statistic show a significant difference (at $\mathrm{p}<0.01$ ) between two genders, in terms of linear combination of the dependent variables (the intrinsic job satisfaction, the extrinsic job satisfaction, the organizational commitment, and the organizational citizenship behavior). In addition to study the linear combination of variables, each variable was analyzed. The results are presented in table 3.

Table 3: The Male and Female Difference in Each of Dependant Variables (the intrinsic job satisfaction, the extrinsic job satisfaction, the organizational commitment, and the organizational citizenship behavior)

\begin{tabular}{lllll}
\hline Variables & df & mean squares & F & \\
\hline $\begin{array}{l}\text { Intrinsic job } \\
\text { satisfaction }\end{array}$ & 1 & 51.652 & 94.707 & 0.193 \\
$\begin{array}{l}\text { Extrinsic job } \\
\text { satisfaction }\end{array}$ & 1 & 51.406 & 148.676 & 0.272 \\
$\begin{array}{l}\text { Organizational } \\
\text { commitment }\end{array}$ & 1 & 15.737 & 22.904 & 0.055 \\
$\begin{array}{l}\text { Organizational } \\
\text { citizenship behavior }\end{array}$ & 1 & 9.266 & 36.074 & 0.083 \\
\hline
\end{tabular}

\subsection{Second Hypothesis}

There is a significant difference between the intensity of correlation between job satisfaction, the organizational commitment, and the organizational citizenship behavior variables in male and female teachers. 
To test the second hypothesis, the correlation coefficients between variables were calculated in male and female teaches. Its matrix was presented in table 4 . As the table shows, it can be seen that all correlation coefficients between variables except between male teachers' organizational commitment and extrinsic job satisfaction $(\mathrm{r}=0.085)$, the female teachers' organizational commitment and extrinsic job satisfaction $(r=0.045)$, and the female teachers' organizational citizenship behavior and extrinsic job satisfaction $(r=120)$ are statistically significant. It indicates that extrinsic job satisfaction have no significant role in explaining the organizational commitment and organizational citizenship behavior in both genders. Moreover all correlation coefficients between variables (either significant or non-significant) are more in male teachers in comparison to female teachers. Thus, the second hypothesis which expresses the more correlation coefficients in male teachers is confirmed. Moreover, in other parts of hypothesis, there was a discussion about significant difference between correlation coefficients in male and female teachers. Also, Fisher's Z Test for each pair of correlation coefficients which are statistically significant (except correlation between intrinsic job satisfaction and extrinsic job satisfaction) approve this hypothesis. Thus not only the correlation coefficients between variables in male teachers are more, but they have significant difference $($ at $\mathrm{p}<0.01)$ with correlation coefficients in female teachers.

Table 4: Correlation Matrix between Intrinsic Job Satisfaction, Extrinsic Job Satisfaction, Organizational Commitment, and Organizational Citizenship Behavior in Male and Female Teachers in Separate Columns

\begin{tabular}{|c|c|c|c|c|c|c|c|c|c|c|c|c|}
\hline \multirow[b]{2}{*}{ Variables } & & \multicolumn{2}{|l|}{1} & \multirow[t]{2}{*}{$\mathrm{Z}$} & \multicolumn{2}{|l|}{2} & \multirow[t]{2}{*}{ Z } & \multicolumn{2}{|l|}{3} & \multirow[t]{2}{*}{ Z } & \multicolumn{2}{|l|}{5} \\
\hline & & Male & Female & & Male & Female & & Male & Female & & Male & Female \\
\hline intrinsic job & Male & 1 & & & & & & & & & & \\
\hline satisfaction & Female & - & & 1 & & & & & & & & \\
\hline extrinsic job & Male & 0.415 & - & & 1 & & & & & & & \\
\hline satisfaction & Female & - & 0.15 & - & - & 1 & & & & & & \\
\hline organizational & Male & 0.230 & - & & 0.85 & - & & 1 & & & & \\
\hline commitment & Female & - & 0.117 & 11.6 & - & 0.45 & & - & 1 & & & \\
\hline organizational & Male & 0.387 & - & & 0.141 & - & & 0.320 & - & & 1 & \\
\hline $\begin{array}{l}\text { citizenship } \\
\text { behavior }\end{array}$ & Female & - & 0.211 & 19.5 & - & 0.120 & & - & 0.250 & 7.7 & - & 1 \\
\hline
\end{tabular}

Analysis matrix which was used in testing the second hypothesis is the base of analysis in Structural Equation Modeling (SEM). As is clear, there is also significant correlation between coefficients, but none of the above coefficients are more than 0.9; which means that there is not high dispersion between variables.

\subsection{Third Hypothesis}

Fit of given model is different in male and female teachers.

In testing the third hypothesis, at first, the given model was fitted without gender segregation to examine the manner of fit. The results showed that this model does not fit well with the data. In this model, the direct effect of extrinsic job satisfaction on organizational commitment and organizational citizenship behavior was obtained which was not significant. This result is not unexpected, since the correlation coefficient between extrinsic job satisfaction and organizational commitment and organizational citizenship behavior was not significant in both genders.

After examining the modified model, then the given model was fitted separately in male and female teachers and Goodness of Fit Indexes (GFI) were obtained which are presented in table 5.

Table 5: Goodness of Fit Indexes of Modified Model in Male and Female Teachers

\begin{tabular}{llllll}
\hline Models & /df & RMSEA & GFI & AGFI & CFI \\
\hline Female Teachers Model & 1.84 & 0.47 & 0.93 & 0.90 & 0.99 \\
Male Teachers Model & 1.43 & 0.44 & 0.94 & 0.91 & 0.99 \\
\hline
\end{tabular}

Based on a comparison between the above indexes can be concluded that each of the models fit well with the data which indicates the generality of modified model. Also the fit of male teachers' model is better than female teachers' model which is expected regarding more correlation between variables in male teachers. Therefore this analysis confirms the research third hypothesis.

\subsection{Fourth Hypothesis}

Direct and indirect effects are significantly different in male and female teachers. 
To test the fourth hypothesis, the direct and indirect effects in male and female teachers' models were examined. The results are presented in table 6 .

Table 6: The Direct and Indirect Effects of Intrinsic Job Satisfaction, Extrinsic Job Satisfaction, Organizational Commitment to Citizenship Behavior, and Organizational Commitment to Intrinsic and Extrinsic Job Satisfaction in Male and Female Teachers' Models

\begin{tabular}{|c|c|c|c|c|c|c|c|c|}
\hline & Direct/indirect effects & & & Male & & Female & & \\
\hline & & & B & & $\mathrm{t}$ & B & $\mathrm{t}$ & $\mathrm{Z}$ \\
\hline direct & $\begin{array}{l}\text { From Intrinsic Job Satisfaction } \\
\text { to Organizational Commitment }\end{array}$ & 0.24 & & 3.26 & 0.14 & 2.19 & 0.94 & \\
\hline & $\begin{array}{l}\text { From Intrinsic Job Satisfaction } \\
\text { to Organizational Citizenship } \\
\text { Behavior }\end{array}$ & 0.35 & & 4.96 & 0.20 & 2.78 & 0.94 & \\
\hline & $\begin{array}{l}\text { From Organizational } \\
\text { Commitment to } \\
\text { Organizational Citizenship } \\
\text { Behavior }\end{array}$ & 0.26 & & 3.72 & 0.25 & 3.39 & 0.94 & \\
\hline indirect & $\begin{array}{l}\text { From Intrinsic Job Satisfaction } \\
\text { to Organizational Citizenship } \\
\text { Behavior }\end{array}$ & 0.06 & & 2.48 & 0.5 & 2.01 & 0.94 & \\
\hline
\end{tabular}

Based on comparison, the difference between direct and indirect effects is not significant which means that despite the more intensity of direct and indirect effects in male teachers' models in comparison to female teachers' model, but there is no significant difference between the models. The result provides another reason for generality of modified model between genders. Therefore hypothesis related to significant difference between direct and indirect effects in male and female teachers' models is rejected.

\subsection{Fifth Hypothesis}

The ability of male and female teachers is different in explaining the organizational citizenship behavior.

The Multiple Regression was used for testing this hypothesis. The results are reported in table 7:

Table 7: The Ability of Male and Female Teachers is Different in Explaining the Organizational Citizenship Behavior

\begin{tabular}{lllllll}
\hline Models & predictor & Criterion & & F & df \\
\hline Male & Intrinsic Job Satisfaction and & Organizational & Citizenship & 0.206 & 25.411 & 2 \\
Teachers & Organizational & Behavior & & & & \\
& Commitment & & & & & \\
Female & Intrinsic Job Satisfaction and & Organizational & Citizenship & 0.096 & 10.419 & 2 \\
Teachers & Organizational & Behavior & & & & \\
& Commitment & & & & \\
\hline
\end{tabular}

Regarding the comparison between the value of explanation in male model (: 0.206) and in female model (: 0.206), can conclude that both values are statistically significant (o.1) but the value of explanation is more in male teachers. Thus, the hypothesis related to male and female model difference in ability to explain organizational citizenship behavior is confirmed.

\section{Discussion and Conclusion}

The result of research significantly shows that the organizational citizenship behavior in female teachers is significantly more in comparison to male teachers (first hypothesis). Organ and Ryan (1995) believe that gender is one of the predictors of organizational citizenship behavior and it is expected that women in comparison with men have been excelled in sacrifice and courtesy aspects. Kidder (2002) using Gender Role Theory to explain the women superiority in organizational citizenship behavior argues that cultural expectations and gender-specific features lead to information of these characteristics in women. Gholipur et al. refer to these characteristics as clichés (stereotype) which include spirit of cooperation, apprehensions, altruism, relationship-oriented, gregariousness, empathy, 
interpersonal orientation, and so on. These characteristics have resulted in that the organizational citizenship behavior of women is more than men. Kidder and Mc Lean Park (2001) believe that organizational citizenship behavior of women is more in female-dominated jobs. Since teaching especially in elementary education, is considered as a female job and the percentage of women employed in elementary schools is more than men (Clicker \& Ladman, 1999), it is expected that organizational citizenship behavior of women be more than men.

Hadsun (1989, cited in Marsden et al., 1993) believes that women job satisfaction is always more than men, because women are less affected than men by inappropriate condition of job.

Some teaching features in the elementary education (such as the feminine nature of job, low salary and the low position of job (prestige) have led to declining men 's desire to accept teaching as their jobs (Gamble \& Wilkins, 1997).

Ben-Perutz (1996) by expressing another reason, argues that there is a significant difference between male and female teachers regarding the value of job and their reason for career choice. Huber man (1993) believes that women are more interested in choosing teaching, while the men consider teaching as an opportunity beside other job opportunities.

As was noted, like two other variables, organizational commitment in male and female teachers is significantly different, and women have more commitment (first hypothesis). The results are in contrast with the view of who advocated the men organizational commitment superiority. They believe that the women have more commitment to family roles than job roles.

Marsden et al. (1993) argue that according to career pattern, the male organizational commitment is always reported more than women, because the men are more affected than women by organizational and occupational factors and are more sensitive to them than women. But in gender pattern some issues like attachment and affiliation to family, marriage, and child birth are posed that decrease both gender organizational commitments to organization, but these factors affect women more than men.

The other result of the research was that the relationship between organizational citizenship behavior, job satisfaction, and organizational commitment was more in male teachers in comparison to female teachers and the difference between correlation coefficients particularly between intrinsic job satisfaction, organizational commitment, and organizational citizenship behavior was statistically significant (second hypothesis). This result was consistent with the findings of other research which have reported that the relationship between variables is higher and more in men. Madsen (1995) believes that lack of job satisfaction in male and female have the same attitudinal (organizational commitment) and behavioral (citizenship behavior) reactions in male and female. Generally, in the same condition the independency of variables is higher in female employees.

It can be expected that despite the female low job satisfaction, the female teachers have more organizational commitment and behavior further than the duty to help students, because the spirit of cooperation, altruism, relationship-oriented, gregariousness, empathy, interpersonal orientation were reported to be more in female teachers. But particularly in teaching job and in inappropriate condition, the relationship between attitudes and organizational citizenship behavior is stronger in male in comparison to female. In other words, organizational citizenship behaviors in men reduce probably due to lack of job satisfaction and organizational commitment.

Therefore, regarding the more relationship between variables in male teachers, other findings of research about better goodness of fit in male teachers and their explanatory power (third and fifth hypotheses) is not so surprising.

The research results in general emphasize the role of gender differences in studying the organizational citizenship behavior, job satisfaction, and organizational commitment.

\section{References}

Allen, T.D., \& Rush, M.C (2006). The influence of rate gender on rating of organizational citizenship behavior. $\begin{array}{lllll}\text { Journal of } & \text { Applied }\end{array}$ http://dx.doi.org/10.1111/j.1559-1816.2001.tb00191.x

Bullecourt, M., Boulanger, G., \& Snell, S. (2008). Managing Human Resources (5th Canadian Edition). Thomson-Nelson.

Ben-Perez, M. (1996). Women as teachers: Teachers as women. In I. Goodson A. Hargreaves (Eds.), Teachers Professional lives. London: Falmer. 
diPaola, M, Tarter, C., \& Hoy, W. k. (2005). Measuring organizational citizenship in schools: The OCB Scale. In Wayne K. Hoy \& Cecil Miskel (Eds.) Leadership and Reform in American Public Schools. Greenwich, CT: Information Age.

Gamble, R. J., \& Wilkins, J. (1997). Beyond tradition: Where are the men in elementary education? Contemporary Education, 68(3), 1187-1193.

Huberman, M. (1993). The lives of teachers. London: Cassell.

Kidder, L. K. (2002). The influence of gender on the performance of organization citizenship behaviors. Journal of Management, 28, 629-648. http://dx.doi.org/10.1177/014920630202800504

Kidder, D. L., \& Mclean Parks, J. (2001). The good soldier: Who is s(h)e? Journal of Organizational Behavior, 22, 939-959. http://dx.doi.org/10.1002/job.119

Klecker, B. M., \& Loadman, W. E. (1999). Male elementary school teachers' rating of job satisfaction by years of teaching experience. Education, 119, 504-514.

Marsden, P. V., Kalleberg, A. L., \& Cook, C. R. (1993). Gender Differences in Organizational Commitment: Influences of Work Position and Family Roles. Work and Occupations, 20(3), 368-390. http://dx.doi.org/10.1177/0730888493020003005

Mason, S.E. (1995). Gender differences in job satisfaction. The Journal of Social Psychology, 153(2), 143-51. http://dx.doi.org/10.1080/00224545.1995.9711417

Oplatka, I. (2009). Organizational citizenship behavior in teaching: The consequences for teachers, pupils, and the schools. International Journal of Education Management, 23(5), 379-389. http://dx.doi.org/10.1108/09513540910970476

Organ, D. W. (1988). Organizational Citizenship behavior: The good soldier syndrome. Lexington, MA: Lexington Books.

Organ, D. W., \& Ryan, K. (1995). A meta-analytic review of attitudinal and dispositional predictors of organizational citizenship behavior. Personnel Psychology, 48, 775-802. http://dx.doi.org/10.1111/j.1744-6570.1995.tb01781.x

Podsakoff, P. M., Mackenzie, S. B., Paine, J. B., \& Bachrach, D. G. (2009). Organizational Citizenship Behaviors: A Critical Review of the Theoretical and Empirical Literature and Suggestion for Future Research. Journal of Management, 26, 513-563. http://dx.doi.org/10.1177/014920630002600307

Wanxian, L., \& Weiwu, W. (2007). A demographic study on citizenship behavior as in-role orientation. Personality and Individual Differences, 42, 225-234. http://dx.doi.org/10.1016/j.paid.2006.06.014 